\title{
Facts and fiction in public economics: How behavioral and experimental economics can inform public policy
}

Citation for published version (APA):

Riedl, A. M. (2006). Facts and fiction in public economics: How behavioral and experimental economics can inform public policy. Universiteit Maastricht. https://doi.org/10.26481/spe.20061012ar

Document status and date:

Published: 12/10/2006

DOI:

10.26481/spe.20061012ar

Document Version:

Publisher's PDF, also known as Version of record

\section{Please check the document version of this publication:}

- A submitted manuscript is the version of the article upon submission and before peer-review. There can be important differences between the submitted version and the official published version of record.

People interested in the research are advised to contact the author for the final version of the publication, or visit the DOI to the publisher's website.

- The final author version and the galley proof are versions of the publication after peer review.

- The final published version features the final layout of the paper including the volume, issue and page numbers.

Link to publication

\footnotetext{
General rights rights.

- You may freely distribute the URL identifying the publication in the public portal. please follow below link for the End User Agreement:

www.umlib.nl/taverne-license

Take down policy

If you believe that this document breaches copyright please contact us at:

repository@maastrichtuniversity.nl

providing details and we will investigate your claim.
}

Copyright and moral rights for the publications made accessible in the public portal are retained by the authors and/or other copyright owners and it is a condition of accessing publications that users recognise and abide by the legal requirements associated with these

- Users may download and print one copy of any publication from the public portal for the purpose of private study or research.

- You may not further distribute the material or use it for any profit-making activity or commercial gain

If the publication is distributed under the terms of Article $25 \mathrm{fa}$ of the Dutch Copyright Act, indicated by the "Taverne" license above, 


\section{Facts and Fiction in Public Economics}

How Behavioral and Experimental Economics Can Inform Public Policy 
Realisatie: Océ Business Services, Maastricht.

ISBN $90 \cdot 5681-247 \cdot 5$

NUR 882

Alle rechtell worbehouden. Niets uit deze uttgave mag worden verveevoudigd opgeslagen in een geautomatiseerd gegevensbestand of openbaal gemaakt, zonder voorafgancle toe stemming van de auteur of de uitgever 


\section{Facts and Fiction in Public Economics}

How Behavioral and Experimental Economics Can Inform Public Policy

Inaugurele rede

uitgesproken bij de aanvaarding van het ambt van Hoogleraar Public Economics aan de Faculteit der Economische Wetenschappen en Bedriffskunde van de Universiteit Maastricht

op 12 oktober 2006

door

Professor dr. Arno Riedl 
After consulting my advisory board of experimental and behavioral economists, I am confident that the refroming proposed in the new public policy program will increase subjective well-being by 34 percent and pro-social orientation by 27 percent at almost no cost (stolen from Amir et al., 2005, re-phrased by the author.

Mijnheer de Rector Magnificus, Leden van de Universitaire Gemeenschap. Geachte collega's,

Dames en heren,

Most, if not all, recent policy choices in the Netherlands and elsewhere strongly rely on the traditional economic concept of rational economic man and woman, the homo economicus. A prominent example in this respect is the reform of the health insurance system in the Netherlands. Another one, the reform of the markets for the supply of gas and electricity. In all cases important principles of the reforms are (i) more competition between suppliers, and (ii) more choice possibilities for the consumers. The main arguments in favor of such reforms are based on the received wisdom among economists that increased competition and an enlianced choice set for consumers is ultimately (consumer) welfare increasing.

To a large extent the presumed positive outcomes rely on the assumption that consumers will exercise their power to choose. For the energy market reform, the expectations about the exercise of consumer power have been largely disappointed, however. At least if one measures this power by the fraction of consumers changing the supplier. Only a negligible fraction of consumers switched to an alternative electricity or gas provider. After the reform of the health insurance sector consumers seem to take up their power to choose. The Nederlands instituut woor onderzoek van de gezondheidszorg (NIVEL) reports on June 15,2006, that with the introduction of the new health insurance system in total 21 percent of consumers have changed their insurance company. However also this switching behavior looks less impressive if one takes into account that a 
majority of those individuals who switched the insurance company did this within a so-called collective agreement: So, at the end, only about 9 percent of all 'switchers" decided to do so on an individual basis.

However, any well-trained economist would now argue that (non-) switching behavior per se does not yet mean that consumers did not make the correct choices. Indeed, revealed preference theory tells us that those who did not switch simply reveal that they had already chosen their utility maximizing insurance package and/or energy supplier and, hence, had no reason to switch.

But let us be a little bit skeptical and ask if there is any way to assess if consumers indeed made 'good' choices. Unfortunately, there is no study (at least I am aware of) that investigates this question for the mentioned reforms in the Netherlands in a systematic way. However, an evaluation of a similar reform of the Swedish social security system in 2000 may help us to get clues about how such reforms may work out and whether consumers indeed make the good choices standard economic theory assumes. Henrik Cronquist and Richard $H$. Thaler (Cronquist and Thaler, 2004) investigated consumer choice behavior after the introduction of the new system. In this system participants are allowed to form their own portfollios. There is also one 'default' fund that is selected automatically for those who do not actively choose. The authors asked if, compared to the default, active choices ${ }^{3}$ are better choices. They conclude that "it would be hard to make the case on an ex ante basis that the actively selected portfolios were better than the default fund" (Cronquist and Thaler, 2004, p.427). ${ }^{2}$ In addition, in the first three years the actively chosen funds did also worse in terms of returns. Another interesting observation is that after the Swedish government reduced the campaigns advertising active choice most people (90 percent) opt for the default fund and almost nobody makes any changes to the chosen port follo or switches the chosen fund.

1. When the systern was introduced in 2000 two thirds of participants actively selectedi a portfolio on their own.

2. In particular in comparis on to the default fund, actively chosen portiolios contained a higher equity exposure and much more local concentration (e.g., aimost 50 percent of the equities are from swedish firms), required more active management, and had higher fees. 
This study strongly indicates that consumers do not (always) make the wise choices standard economic models assume. However, there are too many unobservables (e.g. risk preferences, self-selection effects) that may influence behavior and we may not want to draw too strong conclusions from this field evidence. Therefore, in the remainder of my talk I shall present "clean' evidence that standard assumptions of economic models are indeed often violated and argue that neglecting the observed 'non-standard' behavioral regularities will lead to wrong predictions and worse public policy than necessary. The plan of the rest of talk is as follows. First, I will shortly discuss what experimental and behavioral economics is. Then I shall present important examples of violations of standard behavioral assumptions based on questionnaire studies and laboratory experiments. Thereafter, I shall link up these observations with questions concerning public economics and public policy. I am planning to close my talk with some ideas about interesting and important further research directions and, of course, personal words and acknowledgments.

\section{Experimental economics}

"The principle of science, the definition almost, is the following:

The test of all knowledge is experiment. Experiment is the sole judge of scientific 'truth". (Feynman, 1964, chapter 1)

What precisely is experimental economics? As the name suggests it is the branch of economics that uses experiments to investigate human behavior in economic decision situations. Experimental economics is a method that brings real people to the laboratory (or the fieid) where they make real choices with which they earn (or lose) real money. An important feature of the method of economic experimentation, which distinguishes it from traditional empirical economic research, is that experiments allow the researcher to tightly control the environment in which people make choices. The controllable components of this environment comprise tech.. nologies, initial endowments, action spaces, timing of actions, accessible information, context and to some limited extent also preferences. Varying these elements in a controlled and ceteris paribus way allows causal inference and isolation of true causes of change in human behavior to an extent unattainable by other methods of investigation. Additionally, laboratory experiments can be replicated by other researchers under 
the same or different conditions, thereby assessing the robustness of abtained resuits. As economists, however, we know that there is nothing like a 'free lunch'. An often raised concern about the experimental method is the presumed lack of external validity of the obtained results. This is indeed a serious objection, in particular, when one aims at the use of the experimental method for informing public policy. I shall therefore come back to this issue at the end of my talk.

There are two hard and fast principles which experimental economists subscribe to and which also differentiate economic experiments from most experiments in psychology and marketing. Firstly in economic experiments the monetary earnings subjects receive depend on the choices made by the subjects in a way transparent to participants. The reason for the application of this principle is that it is one thing to merely tell what course of action one would take in a particular situation but another thing to actually take a particular action if it is linked with monetary consequences (Camerer and Hogharth, 1999: Forsythe et al., 1994). Secondly, deception of subjects is effectively banned. The main reason being that once deception is used it is likely that its application will leak out. Subsequently the knowledge of being deceived will spread through the subject population, which seriously undermines an important advantage of experiments, mamely having control over the information and knowledge subjects have concerning the economic situation they are in.

\section{Behavioral economics}

"But also needed is imagination to create from these hinits the great generalizations to guess at the wonderful, simple, but very strange patterns beneath them all, and then to experiment to check again whether we have made the right gues5." (Feynman, 1964. chapter 1)

Behavioral economics is not a synonym for experimental economics although they share some common grounds. Initially behavioral economics strongly relied on empirical evidence generated in psychological and economic experiments. Nowadays, behavioral economics defines itself broader as an approach incorporating evidence - not necessarily experimental - from psychology and other disciplines to explore the limits of existing models of behavior and create new simple ones that can explain actual behavior in a better way than current models 
are able to. Importantly, behavioral economics does not abandon the disciplining strict formality which distinguishes traditional theoretical economic models. It also does not try to fit a new model for each new behavioral anomaly or regularity but rather seeks for parsimonious models and themes that can be applied to many different domains. Behavioral economics is also not another sub-discipline, next to labor economics, public economics or all the other sub economics, but understands itself as a modeling approach which should be applicable to a wide range of economic questions. The ultimate aim being "generating theoretical insights, making better predictions ..., and suggesting better policy."(Camerer and Loewenstein, 2004, p.3) In particular, the latter is also theme of this talk.

\section{Examples of behavioral regullarities}

\section{Presentation and framing effects}

Standard economic reasoning is usually silent about possible effects of the presentation or framing of a decision situation. For instance, from the viewpoint of revealed preference theory it simply does not matter whether one has to make choices in sequence or simultaneously. Rational economic man and woman will always choose according to their true preferences, which are assumed to be well-behaved and coherent, and invariant with respect to superficial variations in the way a choice problem is presented. However, one might start to wonder then why supermarkets and other stores are pricing their products that often with $9.90,19.99$ and similar - just a little bit below round number prices. Is this just co-incidence and does it happen that the true marginal costs of all theses products are exactly these prices? Probably not. ${ }^{3}$

Let me pose the problem more concretely by discussing an example, taken (and adopted) from Simonson (1990) who was among the first to demonstrate with the help of an experiment that it may greatly matter whether consumers have to choose from an array of products simultaneously or sequentially. Suppose you are entering a supermarket today

3. A note for all non-economists: one of the first things we teach osl economic and business students - and what can be found in each elementary economics text book - is that in a world of free trade and competition that is populated with rationall men and women prices of products will equal their marginal production costs. 
and this supermarket offers you to choose one snack out of six different brands of snacks for free. "The same happens in one week from today and in two weeks from today. Hence, in each subsequent week you are free to choose your most preferred snack for free. Now consider another supermarket who also offers free snacks for the next three weeks, again one per week. However, in this supermarket the rule for choosing the free snack is slightly different. Now you have to choose today which brand of snack you would like to receive today, which one you would like to receive in one week and which one you would like to receive in two weeks. Thus, the only difference is that in the second supermarket you choose today for today and the next two times whereas in the first supermarket you decide in each week on the spot.

When faced with such offers, for a homo economicus - and probably also sapiens - to do the right thing is a pretty easy decision. Just choose the brand you like most. Note, that this does not mean that you are going to choose the same brand for each of the three weeks because you might like variety in snacks. Importantly, however, whether the decision has to be made simultaneously or sequentially should not make a big deal of a difference. Consequently, for your choices it should not matter much if you are confronted with the choice sequentially three weeks in a row as in the first supermarket or if you have to choose at once for all three weeks as in the second supermarket. You might not choose the same snack in each week, however, the variety of snacks you choose should not differ under the two conditions. That is, if you would choose Snack 1 in each week in the first supermarket you will also tend to choose snack 1 for all three weeks in the second supermarket. If you choose Snack 2 in week 1 snack 5 in week 2 and Snack 2 in week 3 in the first supermarket you should make sure to receive the same snacks in the same order in the second super market. Now, the question is would you do that? In any event, students in a laboratory study (Simonson, 1990) did not do that, In the sequential choice supermarket 1 condition only 9 percent chose a different snack in each week whereas in the simultaneous choice for sequential consumption supermarket $z$ condition this was the case for 64 percent of participants. These are by no means small differences and even a skeptic should be ready to admit that these results are hard to

4. If you do not like snacks at all you may replace them by brands of other products. e.g. beer or yogurt. 
reconcile with the assumption of stable and /or coherent preferences. In a follow-up study Simonson and Winer (1992) corroborated the labora tory findings in the field by using scanner data of yogurt purchases in a supermarket. They find that the variety of flavors chosen significantly increases with the number of purchases per accasion. The obsenved choices in the laboratory and the supermarket strongly indicate that revealed preferences systematically depend on the way the choice set is presented. A dependence not accounted for in standard economic models. 5

Let me give a second example which probably casts even more doubt on the assumption of coherent and stable preferences in a famous early study - known as the "Asian disease" problem - Tversky and Kahneman (1981) show that choices can strongly depend on how problems are presented. Tversky and Kahneman conducted questionnaire studies with students (Stanford University and Uniwersity of British Columbia) where they asked them to indicate their preference concerning different programs proposed to combat an "unusual Asian disease". To study potential framing and presentation effects the problem was presented in two economically equivallent but presentational different formulations. Figure 1 reproduces the original text.

Problem 1 presents the decision situation in a positive frame by empha. sizing that lives can be saved. Problem 2 , in contrast, presents the wery same options in a negative frame by emphasizing that some people will have to die. Obviously. Programs A in Problem 1 and 2 are identical since in both cases 200 people will be saved and 400 people will die for sure. The same is true for Programs $B_{3}$ where in both problems 200 people will be saved and 400 people will have to die, in expectations. Hence, whatever people like more, there should be no significant difference in revealed preferences between the two problems.

5. These observations are consistent with the concept of "choice bracket nig and its specific consequence of "taste change" (Read at al. 1999). The former refers to the fact that the way people make decisions, narrowly or broadly affects their choices. The latter refers, specifically, to the effect that the choice people make today can change their tastes and, hence, influence their choices in the future. The ernergent property of "diversfication bias" seems to be a robust phenomenon and is repllcated in several studies (see Read et al, 1999 . p.r.gh). 


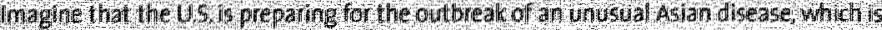

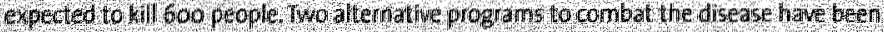
proposed 4 ssune that the exart cientif estimate of the consequences of the prograris artas 1010 w.

\begin{tabular}{|c|c|}
\hline \multicolumn{2}{|c|}{ V V V V } \\
\hline 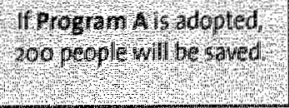 & 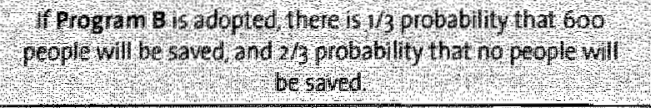 \\
\hline \multicolumn{2}{|r|}{ Which of the two progrons would you fowort } \\
\hline \multicolumn{2}{|c|}{ 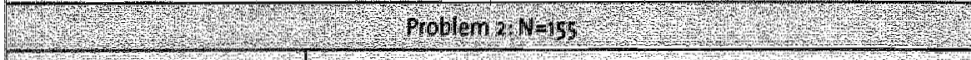 } \\
\hline $\begin{array}{l}\text { Ir program Alchls adopt } \\
\text { ed, } 400 \text { people wil dic. }\end{array}$ & 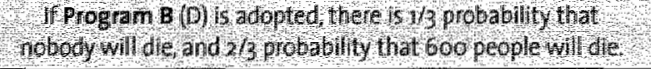 \\
\hline & 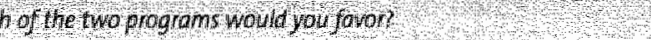 \\
\hline
\end{tabular}

FICUIRE 1 Tiensky and Kahneman's "Asian disease" problems

Figure 2 depicts the frequency of actual choices. When confronted with Problem 1 (positive frame) an overwhelming majority of 72 percent opts for program A that saves 200 people for sure whereas only 28 percent opts for the risky program where 200 people are saved only in expectations. When confronted with Problem 2 a dramatic shift in revealed preferences occur. Now, only a minority of 22 percent goes for the sure outcome of 400 dead people but 78 percent are ready to accept the risky choice where 400 people die only in expectations. It should be obvious that such a strong framing effect effectively inducing 'revealed prefer-

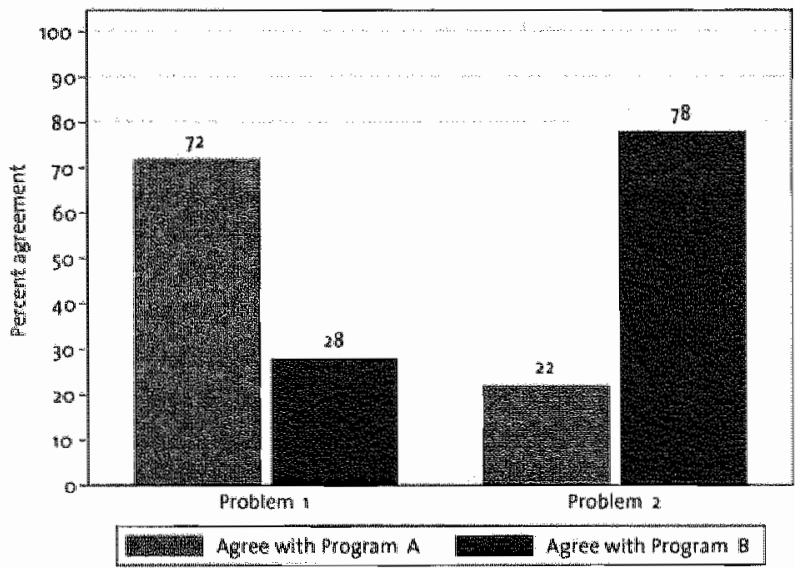

FIGURE z Results of Twersy and Kahneman's "Asian disease" probiems 
ence reversal' is hard to square with the assumption of coherent and stable preferences.

Remark: The offered options in the Tversky and Kahneman study are both rather undesirable. Unfortunately, this makes them representative for many decisions made in the public domain. Consider, for instance, public investment decisions, especially, investment in infrastructure concerning safety. The decilision not to invest in more secure highways or railway infrastructure means to effectively decide to accept deaths that otherwise could have been avoided. Simlarly, not investing into research for an influenza vaccine means to risk avoidable deaths in case of an outbreak of influenza. Many more examples could be given from airport security to school crossing guards ("lollipop man"). ${ }^{6}$

\section{Morality and reciprocity}

"... in situations where self-interest and ethical values with wide verbal allegiance are in conflict. Much of the time, most of the time in fact. the self-interest theory... will win." (Stigler, 1980, p. 176)

Although the neoclassicall concept of utility is broad and flexible - critics might even say tautological and hence without content - and therefore - in principle - not restricted to narrow selfish preference orderings most work and almost all applications in (public) economics assume that people are narrow-minded selfish material wealth maximizers. One might argue that, as long as models based on the assumption of narrow self-interest describe behavior of real people sufficiently well and, hence, make correct predictions that can be used to evaluate and validate public policy there seems to be no reason to abandon such models. This is precisely the argument endorsed by Milton Friedman, who argues that (1) theories should be judged by the accuracy of their predictions, and (2) theories should mot be judged by the accuracy of their assumptions (Camerer, 2005). However, if not only the basic assumptions are counter-intuitive (and empirically proven to be wrong) but allso the models'

6. A nice and harmiess example where firm seems to take framing effects into account is that since recently the Dutch rallways do not use the word "delay" any more when announcing that a train arrives late at the railway station. Unstead, the phrase that "the train whll arrive over a few minutes" is used. 
predictions incorrect or at least misleading then this approach is in deep trouble.

In the following I shall describe two prominent simple games where modtels based on narrow material self-interest turned out to do a bad job in predicting actual behavior. These examples will show that faimess considerations and, in particular, an inclination towards reciprocal behavior are important constituents of human behavior. I shall distinguisth between negotive reciprocity and positive reciprocity. Negative reciprocity describes the tendency to respond to an unkind act with an unkind act, whereas positive reciprocity describes a kind response to a kind course of action.? The following examples will make this differences clear.

\section{Negative reciprocity - the (mini) ultimatum game}

The ultimatum game (Cuth et al., 1982) can be interpreted as a negotiation or bargaining situation that is stripped down to its most important constituents. It is a situation involving two people where one individual can make a take-it-or-leave-it offer to the other individual who can, indeed, take it or leave it. ${ }^{8}$. Figure 3 depicts - for the sake of the argument - an even further boiled down version of the originally investigated ultimatum game (adapted from Falk et al., 2003). There one player, say Peter, has received 10 euro which he has to split between himself and, say Rita, in ai take-it-ar-leave-it way. If Rita accepts the offer then both receive money according to the proposal. If she rejects both ${ }_{3}$ hence Peter and Rita, do not receive any money. Since our players are simple minded we make matters even more simple and give Peter only two possibilities how to split the money. Depending on his morms and values, he can make a rather unkind offer, "I take 8 and you get 2 ", leaving most of the money for himself or he can decide to be kind and propose to split the

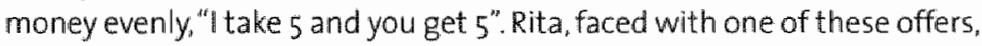
has to decide whether to accept the offer or to turn it down. Standard

7. In a sense positive and negative reciprocity may be wiewed as just two sides of the same medal, since a noll-unkind act is abwously a kind act. However different emotions may be involved (e.g-anger vs joy) with negative and positive reciprocity. which is likely to make the responses psychologically and physiologically different. Additionally reference points of forness are important for the judgment of kind and unkind behavior:

8. Note that swch (or similar) situations are not uncommon in everyday life. For instan$\mathrm{Ce}_{3}$ it is akin to shopping in western supermarkets or shops where one is usually not negotiating the price of the product but rather takes it or leaves it. 


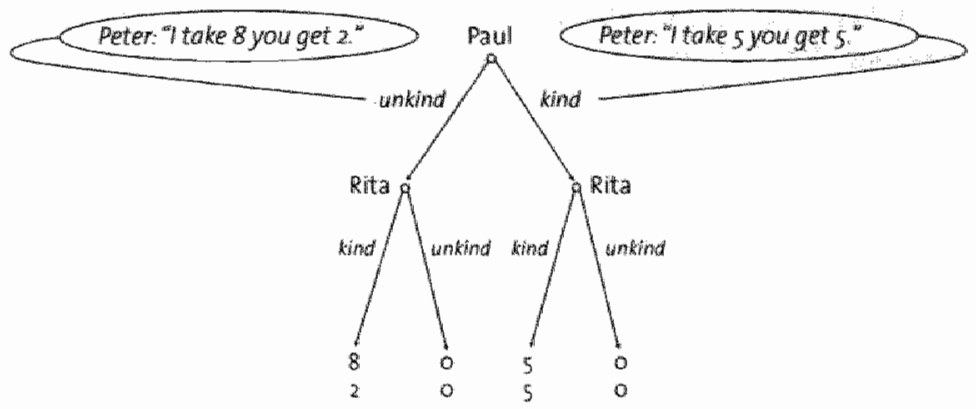

FIGURE 3 The mini utimatum game

economics assuming narrow selfishness tells us that, because more money is better than less money, Rita will accept any offer. In terms of the figure it means that Rita will be kind (accept) after a kind proposall $(5,5)$ and will also be kind (accept) after an unkind proposal $(8,2)$.

The empirical facts, however, differ significantly from this prediction. A typical, qualitatively and quantitatively representative, result generated in many experiments is shown in Figure 4. It shows the percentage of accepted and rejected offers for both possible proposals. As one would expect the kind proposal of $(5,5)$ is never followed by the unkind response of a rejection. The situation looks quite differently, however, if

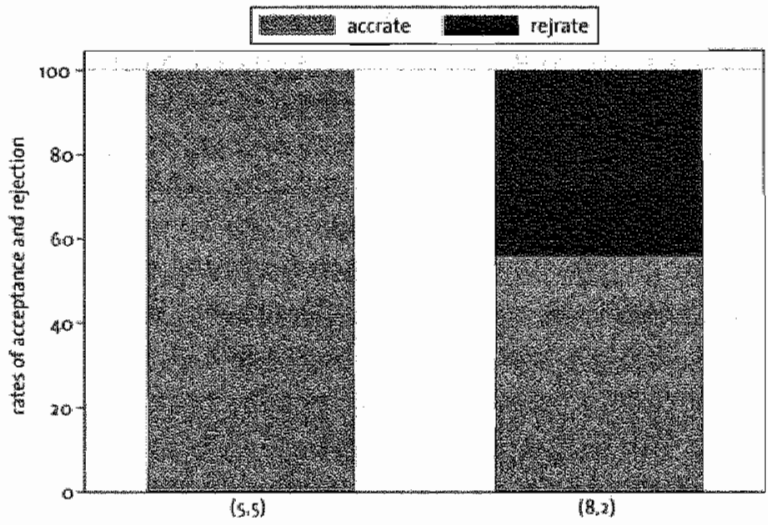

FICURE 4 Acceptance and rejection rates in mini whimatum game (dota source: Folk et al (2003)) 
an unkind proposal of $(8,2)$ is put on the table. Such an unkind proposal is often followed by an unkind response, namely rejection. In the reported experiment this happens in more than $40 \%$ of the cases. It important to see that the unkind response is costly, leaving both players without any monetary gain. This is precisely what makes it incompatible with standard economic reasoning assuming narrow selfishness. 9

\section{Positive reciprocity - the gift-exchange game}

Probably the best known example for the existence of a predisposition towards positive reciprocity stems from a game coined gift-exchange game. In economics, the basic idea behind this game dates back to Akerlof (1982) who argued that gift-exchange is ar important constituent of labor contracts that are genuinely incomplete. The incompleteness of the contract refers to the fact that the effort exerted by an employee is often not contractible because it cannot be observed by the employer andior not be enforced by a third party, like a judge. Akerlof's theoretical model, however, relied on assumptions about economic behavior of employees that are at odds with the standard assumption of narrow selfishness. Namely, that employees respond to higher wages positively, in the sense that higher wages make them exert higher and more costly effort.

In Fehr et al. (1993) (see also Fehr et all., 1998, 1997) this idea is put to a test in the experimental laboratory. Actually, the implemented situation more generally represents any kind of patron-client or principal-agent relationship where contracts cannot be (perfectly) enforced. Consider the following situation (based on Riedl and Tyran, 2005): A number of people is divided into a set of "employers" ("buyers") and a (larger) set of "employees" ("sellers"). The rules of the game are as follows. If an employer hires an employee who provides effort, $e_{\text {, and receives }}$ a wang $w$, then the employers earnings $\pi$ are $30+90 e-w$. That 15 , the employer earns a lump-sum of 30 plus 10 times the effort exerted by the employee minus the wage w paid. The wage is between 1 and 100

9. Actually the rejection rates for offers of only about 20 percent of the whole pie are usually higher than the 40 percent reported here. A likely reason is that Falk et at. (2003) applied the $50-$ Galled strategy method where subjects have to decide upon acceptance and rejection before they know the actual choice. That is, they make ther decision in a cold (emotional) state. whereas responses to artual offers are madie in hot (emotional) states (see Loewenstein, 1999) 
( $1 \leq w \leq 100)$ and the effort between 1 and $10(1 \leq e \leq 10)$ ) The eamings $w$ to the employee is then the wage, $w$, he receives minus a "cost of effort" $c(e)=e$. (u-w-e). The sequence of actions is as follows. The employer first offers a "contract" specifying a wage $w$ (see Figure 5a). A contract is made with the first employee who agrees to these terms (see Figure 5b). When the contract is signed the employee receives the wage before exerting any effort. Only; after the wage is paid out the employee decides on his effort, where he is completely free to choose any level of effort. Importantly, each employer-employee interaction is anonymous and essentially one-shot. (That is, there is no possibility for reputation building or retaliation.)

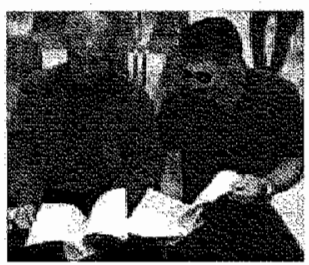

a. Proposed contract

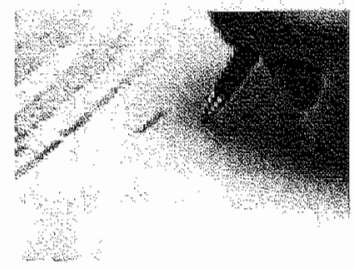

b. Accepted contract

FIGURE 5 Proposing and sigring a contract

What will be the outcome of such an interaction? Consider first the employee who has received a wage and has now to decide on the effort level. Under the standard assumption of narrow selfishness, any employ. ee will choose the effort level with the lowest cost, $e=1$, no matter how high or low the wage received is. In effect, choosing a higher effort levell only decreases his total earnings. A rational and selfish employer will perfectly anticipate this behavior and, hence, offer the lowest possible wage, $w=5$, which is still accepted. ${ }^{\text {no }}$

However, in the experiment this predicted outcome is very rarely observed. Moreover, gift exchange is observed as a very strong behaw ioral regularity. Figure 6 illustrates this. The figure plots on the vertical axis the (average) effort chosen by the employees on the average wage offered by the employers on the horizontal axis. Under the standard assumption of narrow self-interest emplloyees should always choose the 
lowest effort level implying no relationship between effort and wages. This is reflected by the straight line running through $e=1$. The actual data, however, show a strikingly different pattern: effort is clearly and strongly increasing with the wage received. In the figure this is reflected by the increasing. line, which connects average effort lewels for wages smaller than 20 , between 21 and 40,41 and 60 , and larger than 61 . Hence, in conclusion this (and many other studies) clearly show that subjects respond positively reciprocal. An important side effect of the observed gift exchange is that it increases efficiency (in terms of surplus maxim mization) and decreases inequality in earnings, in comparison to the benchmark outcome predicted under standard behavioral assumptions.

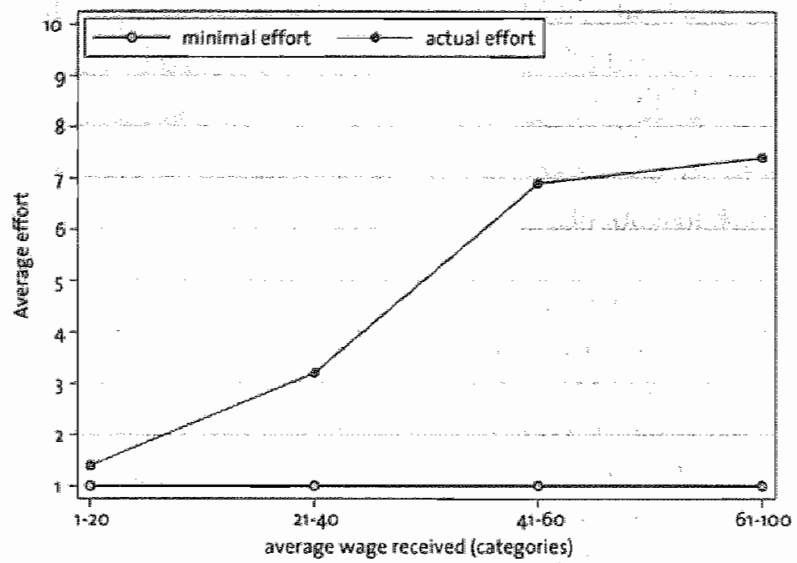

MGURE 6 Gift exchange in an experimental labor market (source. Riedl and Tyran (2005))

\section{Behavloral regularities, public economics, and public policy}

On the interaction between trading institutions, morally, and tax-shifting An interesting and important example where economic institutions and inclinations toward reciprocity interact in a non-terivial way is the case of tax liability side equivalence. Tax liability side equivalence is a basic tenet in public economics. It states that the statutory incidence, that is who is legally responsible to pay a tax, is irrelevant for economic incidence, that is who actually bears the tax burden. In the words of one of the authorities in public economics, Richard A. Musgrave, 
"it is a matter of indifference whether general tax on transactions is assessed on the sellers or on the buyers side of the market" (Murgrove, 1959, p. 351).

Importantly, under standard economic assumptions this holds true independently of the trading enwronment (monopoly, oligopoly, competition, bargaining) provided that prices can in principle adjust freely. Interestingly enough, however, much of the public debate about tax burden (and subsidy benefit) in the media and the political arena is often much concerned with statutory instead of economic incidence. "So the question arises whether the public reasoning or the professional economic reasoning is wrong. For public pollicy the answer to this question is obviously important because it tells us which groups of the society are actually going to pay a tax, and, hence, what the distributional and allocational consequences of $a$ tax are. Neglecting the behaviorally true tax burden and relying (only) on normative prescriptions that are based on incorrect behaviorall assumptions may, therefore, have very undesirable political consequences.

To find out the behaviorally true tax burden, ideally one would like to shift the statutory tax burden from one side of the market, e.g. buyers, to the other side of the market, e.g, sellers, leaving everything else equal. Naturally, such situations do not occur regularly in the field. Fortunately, laboratory experiments are an ideal method to do precisely this. The following shortly reports on three sets of experiments testing tax liability side equivalence under three important economic institutions: competitive markets with complete contracts, bargaining, and gift exchange markets.

Three studies (Borck et al., 2002; Kachelmeier et al., 1994; Ruffle, 2005) experimentally investigate tax (and subsidy) liability side equivalence in competitive markets under various trading mechanisms. The results of these experiments can simply be summarized by: tax liability side equivalence holds in competitive experimental markets independent of the trading institution. Hence, no 'anomaly' there. Standard theoreticall and behavioral tax incidence coincide. Kerschbamer and Kirchsteiger

11. Public and political discussions concerning the Dutch 'mortgage rent discount' (hypotheekrenteaftek) also reflects features of this misperception of tax burdens and subsidy bertefits. 
(2000) give an interesting twist to these results by studying tax liability side equivalence in a simple bargaining environment. They modify the utimatum game (similar to the one described above) such that in case of acceptance of a proposal one of the negotiators has to pay a tax from her gross earnings. In one treatment the proposer has to pay the tax. In a second treatment the statutory tax burden is placed upon the responder. If tax llability side equivalence holds the distribution of earnings should be the same under both tax treatments. However, if statutory tax incidence implies also a moral obligation to actually bear part of the tax burden than tax liability side equivalence breaks down. We know already that in bargaining situations reciprocity and distributional fairness are determinants of economic outcomes. Hence, one might expect that tax liability side equivalence is especially vulnerable in such situations. Indleed, Kerschbamer and Kirchsteiger (2000) find that the side of the transaction that has to legally pay the tax also bears a disproportionall part of the economic tax burden. The observed incompleteness of tax shifting is also economically significant. When the tax liability was taken from the responder and placed upon the proposer the offered net lafter tax) income for responders increased between $20 \%$ and $24 \%$. In contrast. standard tax liability side equivalence predicts no change in net income at all. Therefore, we have a clear case where the interaction between trading institution and moral behavior interact in a way standard theory fails to predict.

Perfectly competitive markets and pure (two person) bargaining situations are at the two extremes of economic trading institutions. Although both are not uncommon they are surely not the most frequent trading institutions. Rather, a mixture of both seems to be the most common one. Gift exchange markets or markets with incomplete (or even no) contracts, as described above, incorporate both elements: competitive market interaction and bilateral bargaining. Riedlland Tyran (2005) investigate tax liability side equivalence in such markets. in one set of experiments buyers are legally obliged to pay a tax and in another set of experiments sellers have the legal obligation to pay the tax. If tax liability side equivalence holds than there should be no difference in the outcomes of real variables between the two tax regimes. However, if moral obligations, as in the study of Kerschbamer and Kirchsteiger (2000), are important then the side on which the tax is levied should also bear a relatively laiger economic burden of the tax. In contrast, to the studies concerning competitive markets and bargaining more real 


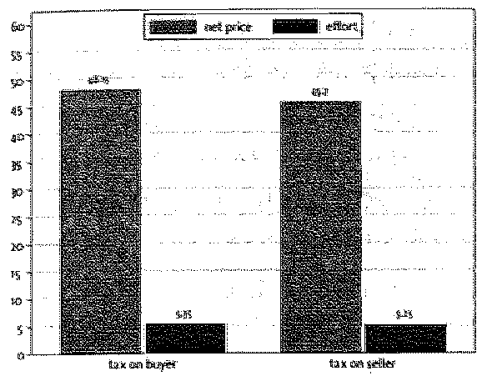

a. Net prices and effort

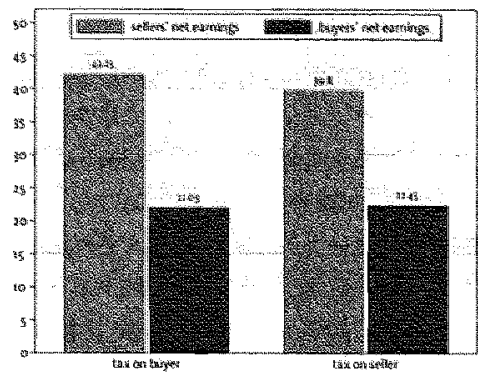

b. Net earnings

FICURE 7 Prices, effort, and earnings under the two tax regimes. (source, Riedl and Tyran (2005))

variables can be investigated in gift exchange markets: net prices, effort and net earnings. Tax liability side equivalence may fail on each of these dimensions with different consequences for the final distribution of income.

Figure 7 depicts average net prices and exerted efforts (panel a) and average net earnings (panel b) for both, taxes levied on buyers and taxes levied on sellers. From the figure it is obvious that there are no large differences between the two tax regimes on all three dimensions of comparison, net price, effort, and net earnings. Furthermore, the observed small differences are neither statistically nor economically significant. This is an important but also somehow puzzling result given the observation that tax liability side equivalence breaks down in pure bargaining and not when it is coupled with a competitive market. It strongly sug. gests that market desigm and perceptions about moral obligations to pay a tax interact in a non-trivial way with real and economically significant results in terms of tax shitting.

One conclusion to be drawn from these studies is that researchers as well as policy makers should not solely rely on standard economic theorizing when assessing the economic burden of a tax. Additionally, the institutional environment and its interaction with moral and reciprocal behavior seems to be crucial for the actual outcome. Where the precise borders of validity of the standard economic model lie is still much of an empirical question, however. If we want to understand under which circumstances tenets like tax liability side equivalence indeed hold or 
- more importantly - have to be adapted we need a research program that systematically evaluates such economic wisdoms. ${ }^{12}$

\section{Identifiable victims and hidden toxes}

Real outcomes can be non-trivially influenced not only by the interaction between institutional design of trading institutions and behavior of economic agents but also allready through pure presentation effects. In a 1968 article Thomas Schelling noticed that "The life you save may be your own" and that "the death of a particular person evokes anxiety and sentiment, guilt and awe,... [but that] ... most of this awesomeness disappears when we deal with statistical death" (5chelling, 1968). This is probably the first account by an economist pointing towards how different we perceive identifiable and statistical victims. Loewenstein et al. (2006) take up this issue and examine the public policy consequences of this human inclination to have stronger feelings towards an identifiable victim than towards a statistical victim. They argue that from a welfare economics point of view "people may be insufficiently sympathetic towards statistical victims". Mainly psychological research strongly supports the thesis that individual concrete cases have a much more powerful motivational effect than statistics. This seems to be the case even if the statistics is objectively more informative than the individual case. A typical example in this respect is that peoples opinion about the abuse of welfare payments is shaped much more strongly by individual experience than by objective statistics.

An important public policy implication of the identifiability effect is that "hidden taxes" tend to be much more popular than other taxes. For example, the value added tax is for most consumers (including economists) simply part of the purchase price of a commodity and, hence, has no identifiable victim. This concealment may make it politically easier to raise rather value added taxes than other taxes. Other prominent examples of "hidden taxes" are withholding income taxes which makes people think that the money transferred to the tax authority is not their own and corporate income taxes which makes people belief that shareholders pay the tax although it is very likely that the actual burden of the tax is borne

12. Airst very preliminary attempt into this direction is made by Burgers (2004).

13. For clean evidence from the laboratory (dictator gamel as well as the field (housing for needy) see small and Loewenstein (2003). 
by labor (Mc Caffery, 1994; McCaffery and Baron, 2006). In the mertioned examples the lack of identifiability makes the taxes themselves as well as an eventual increase of them much more acceptable then it would be the case for non-hidden taxes. The psychological appeal of hidden taxes is nicely summed up by the aphorism of Russell Long, one of the most powerful and influential tax legislators as chairman of the U.S. Senate Finance Committee "Don't tax him, don"t tax me, tax the man behind the tree" (quoted after Small and Loewenstein, 2003).

\section{Endogenous preferences and competition}

One central assumption in economics is that people have "fixed lifetime preferences" (Bernheim and Rangel, 2005). In particular, this means, preferences are assumed not to change across states of nature of institutional constraints. In this perspective, preferences are exogenously fixed and independent from the environment an individual is immersed in. In contrast to this traditional view, Samual Bowles (Bowles, 9998 ) argues vividly in favor of endogenous preferences. He claims that our preferences are not well defined and stable but rather strongly depended on the environment we have to deal with. However, all the evidence he puts forward in support of his claims is either indirect or is open to alternative interpretations.

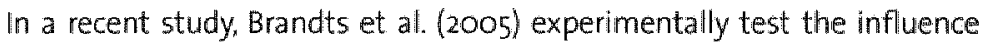
of trading institutions on subjective well-being and (social) preferences directly. In this experiment subjects are divided into two groups. One group interacts in a competition free environment whereas subjects in the other group interact in a competitive environment. The hypothesis is that the experience of competition versus no competition per se leaves its traces in subjects' well-being (in the sense of Kahneman et al. (1997)'s 'experienced utility') and in their social preferences (that is, their 'social disposition towards others'). To test this hypothesis methods from social psychology are combined with experimental econamics. At the beginning of the experiment subjects are asked to perform a social value orientation test, which measures subjects' social preferences by letting them allocate real money between themselves and some anonymous other person. The same test is conducted also after subjects had experienced a competitive or a non-competitive environment. Hence, social preferences are measured before and after the experience with a particular trading institution. If standard economic reasoning is corred then there should be (at least) no difference in the change of social orientation of subjects in the competitive 


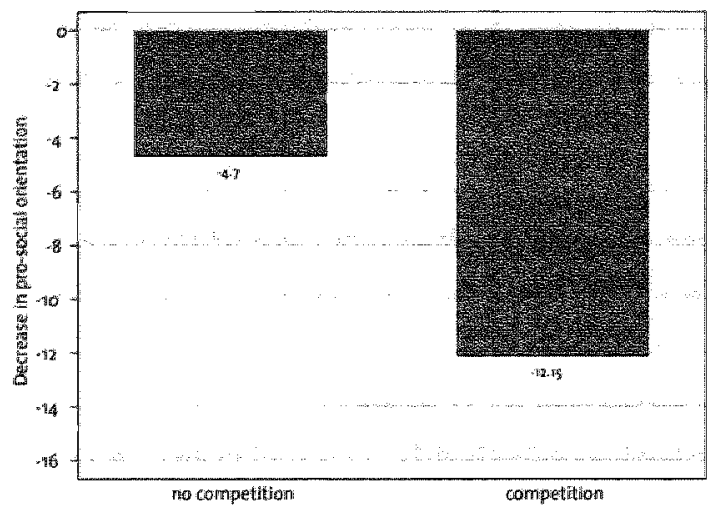

FIGURE 8 Change in social preferences in competiti ive and non-competitive environment (source: Brondts et ol. (2005))

and those in the non-competitive environment. This is not what we find. Firstly, there is a difference in the social orientation of subjects experiencing different institutions, and secondly, within the competitive institution the social orientation differs strongly between subjects in different roles (i.e. being on the long or the short side of the trade relatianship).

Figure 8 gives an impression of the differences in social preferences between the competitive and the non-competitive environment. It shows the change in social orientations from before to after the experience with the competitive and the non-competitive environment, respectively. Interestingly, under both trading regimes pro-social orientation deteriorates. Importantly, however, the decrease after the competitive experience is almost three times as large as when subjects experience no competition. This clearly indicates that preferences are indeed not - or at least only partly - exogenously given and strongly shaped by subjects' institutional experience. An additional result of this study is that not only social orientation deteriorates under competition but that subjects" also suffer a loss of experlenced utility.

In public and political debates in the Netherlands and many other coumtries reforms aiming at more competition are often backed up with the argument that consumers will be better off in the presence of more competition. This argument refers to the notion of consumer surplus

44. For clarity of presentation only the strongest change in social preferences is shown for the competitue environment. 


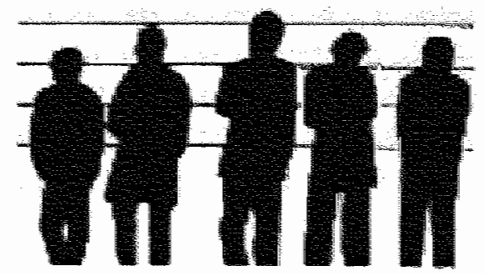

FIGURE 9 Typlcal police ineup

which value is (in practice) measured only in purely material terms. This surplus may indeed increase with more competition and less regula. tion (although in the experiment discussed above even this is not the case). However, the ultimate aim of welfare economics and public policy should be the maximization of the citizens" well-being. In this sense, the findings of deteriorating social orientations and suffering subjective well-being puts question marks behind the supposedly purely positive effects of more competition and less regulation. Unfortunately, there is no generally accepted measure of subjective well-being developed, yet, and much more research into the measurement and determinants of well-being is necessary. ${ }^{15}$. 15

Finally, let me try to close the circle with two examples where research into presentation and framing effects can wery concretely inform public policy and thereby increase general well-being. The first one is taken from Amir et al. (2005) and highlights the importance whether a decision task is presented simultaneously or sequentially. In many places police lineups are used to identify suspects of crime. In such a lineup eyewitnesses of crimes attempt to recognize one person in a group of suspects standing next to each other (Figure 9). Evidence from psychological research casts serious doubts on this much used method of identification. Lindsay and Wells (985) designed a clever experiment and

14. Recently some progress is booked concerning the measurement of subjectiwe well. being. Kahneman and Krueger (2006) introduce a measure based on gelfreports of peoples' emotional states (see also irandts tet al. 2005 ).

16. Casual evidence also indicates that institutions indeed shape social onentatton and well.being. The often heard complaints that "life on street in the Netherlands is less pleasurable than it once was because too many people do not show promocial behavor any more and that there developed "chimate of selfishness (zelfgenoegzadmbetid") which makes life less pleasurable are wivid, though non-scientific, witnes ses thereof. 
showed that the likelihood of false identification of an innocent subject is much higher under simultaneous than under sequential lineup. At the same time the frequencies of correct recognition of the guilty suspect did not differ significantly between the two conditions. This, together with subsequent research, clearly shows that in identification tasks - as police lineups - the approach to present items or individuals one at a time leads to better, less biased, judgments than the practice of presenting severall individuals simultaneously. The straightforward and unambiguous policy recommendation is, therefore, to abandon simultaneous lineups in favor of sequential lineups. Actually, at least two U.S. American states have adopted the alternative methodology.

The organization of organ donation is a another important domain where it has been shown that framing effects can crucially alter behavior and, in this case, make the differemce between life and death. Johnson and Goldstein (2003) investigate and compare two different organ donation systems around the world. They distinguish between two so-called noaction defaults. No-action defaults are the choices implicitly imposed on individuals who do not take an active decision. In the case of organ donation the most widely used default decisions are "presumed-consent" and "explicit-consent". Presumed-consent means that people are assumed to be organ donors as long as they do not actively indicate otherwise. Explicit-consent means that individuals have to actively register for being a donor, otherwise they are not. The authors investigate the effective consent rates for being a donor across the two defaults experimentally as well

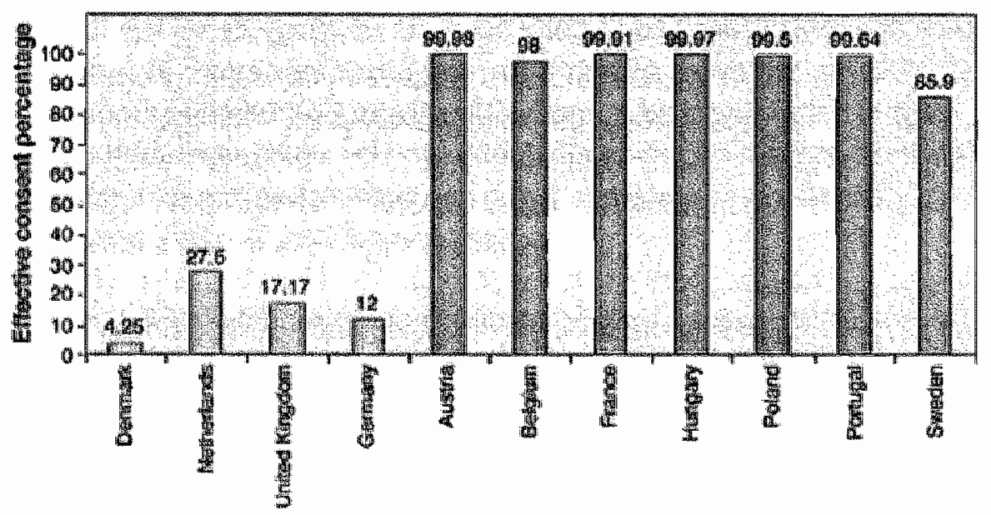

FGURE to Effective consent rates in cowtries with explicit consent four leftmost barsh and presumed consent (seven rightmost bars) (soumce: Science 3022006 p. 3338 ) 
as by cross-country comparisons. Recall, that standard economic theory assumes that preferences are fixed and known to the economic agent: This implies that for effective consent rates it should not matter whether one or the other default option is taken. Figure vo shows the facts: The four leftmost bars depict effective consent rates for four countries (Denmark: the Netherlands, UK, and Germany) which apply the explicit-consent as default. The bars to the right show effective consent rates for countries with presumed-consent as default. The differences are striking. Whereas in the explicit consent countries the effective consent rates are maximally 27.5 percent (the Netherlands), the minimum consent rate in countries with presumed consent is 85.9 percent (Sweden). These differences are surely too large to be explained by effort or transaction costs of actively opting in and opting out in the explicit consent and presumed consent countries, respectively. To exclude also this potential explanation the authors conducted an experiment where effort and transaction costs were virtually zero. In the experiment the difference in effective consent. rates between the two default options is slightly smaller than in the cross: country study but still a long way off from being equal. Interestingly, a neutral framing without any default led to the same effective consent rate then the presumed consent default. This allows the conclusion that the unbiased 'true' preferences concerning organ donation are better ellcited with presumed consent then with explicit consent.

That some policy makers are - at least sometimes and seemingly in contrast to traditional economists - aware of the fact that default options make a difference is reflected in the discussion about reforming the donor registration system in the Netherlands. In 2005 a coalition of parties in the parliament actually did bring forward a motion that would have changed the explicit consent default into a presumed consent default. At the end, however, there was not enough politicall support for such a radical change of the donor registration system." In any event,

17. A clear case of a presentation and framing effect is also reported in an article of $N R C$ Handelsblad (September 2 \& 3. 2006, pp.4\%-42) about the Duth immigration and naturalisation service (IND) The newspaper reports that if employees of the IND reject an application for a temora ry residence permit ('mathtiging voorloplg verbliffin) they hawe to motiwate their decision in written form. For the case of hardships ("schi). nende gevallen") of asylum seekers the IND ermployees have to motivate the decision if they accept the application. The result being that cases of hardship are hardly ever positwely assesed whereas temporary residence permits are relatively easily issued. 
this example highlights an issue where insights from behavioral and experimental research are related to important political decisions and can inform public policy more accurately than standard economic reasoning would be able to.

\section{Further directions: the field and the brain}

In the last part of my talk I would like to discuss two fields of behavioral and experimental economic research that can be of importance also for public economics and public policy.

A common argument of skeptics against the use of laboratory experiments, in general, and as a policy advice instrument, in particular, is its supposed lack of external validity. This is indeed an important concern since if regularities observed in the laboratory do not carry over to the field amy conclusions and advices drawn from these experiments could be dangerously misleading. The potential problem of lack of external validity is not unique to economic (or psychological) experiments. ${ }^{18}$ In physics, the feather and the stone which fall with the same speed in vacuum but with different speeds in 'real life' is a well-known illustrative example. As the wind may blow away the feather outside the vacuum, in economic situations many factors one can control for in the laboratory but not in the real world can influence behavior and blur or even wipe out behavioral regularities observed in the laboratory. One way to tackle this problem is to add pieces of real life context to the 'dry" laboratory environment in a systematic way. In this way one can trace if and how such "pleces of reality" alter behavior. Another important way to check for external validity is to replace the usual student subjects with sub. jects who are experienced with the decision situation at hand and/or are more representative than students. Such experiments have actually been conducted for a variety of decision situations (see e.g. Fehr and List. 2004: Egas and Riedl, 2005, among many others). The general upshot form these experiments is that 'experts' do usually not make significantly different decisions than students in the same situation. A third way to test external validity is to conduct 'field experiments: Field experiments might be seen as a combination of the two already described ways.

18. Note that theoretical reasoning is confronted with exactly the same potential lack of external walidity. 
which pushes them to their limits. Harrison and List (2004) provide a typology of field experiments and define them crudely as experiments where one is "recruiting subjects in the frield rather than in the class" room, using field goods rather than induced valuations, and using field context rather than abstract terminology in instructions" (Harrison and List, 2004, p. 1009-1010). Field experiments are indeed an important complementary method in research that is especially concerned with policy advice. In the ideal case, an economic policy reform is evaluated with all possible scientific methods before a political decision is made. That is, theoretically, experimentally in the lab-and the field, and with traditional applied econometrics. It should be obwious that a thorough scientifically sound examination of a policy reform that reduces the risk of implementing false policies is much cheaper (at least in expectations) than the costs of an actually implemented false policy. A rare example of a first - albeit incomplete - attempt of such a scientific approach to policy issues in the Netherlands (I had the pleasure to be part of) is the evaluation of the so-called "Plan Van Elswijk" which proposes a radical reform of the (Dutch) financing system of unemployment benefits. In the evaluation of this plan simulation studies, laboratory experiments and a small field experiment were conducted (see van winden et al., 1999, 2000; Riedl and Winden van, 2001,2006, 2005, and the references therein).These studies produced a rather clear picture of the likely benefits and disadvantages of the proposed reform. At the end, however, politics chose to interpret the results in a different way than most involved researchers did and, to a large extent, ignored the scientific outcomes. Nevertheless, in conclusion, I am convinced that laboratory experiments together with field experiments will play a much more important role in public policy advice in the future than they do today?

A further - quite different - but potentially equally and in the long run probably even more important stream of research is the recent combination of neuroscience with experimental and behavioral economics. This new research branch - neuroeconomics - uses knowledge about brain mechanisms to study the biological foundations of behavioral regularities obserwed in the laboratory and the field. Kevin McCabe, one of the pioneers in this new field of the behavioral sciences defines it as follows:

19. Am interesting recent example where laboratory experiments informed polltics is given in Jacob K. Goeree et al (2005). 
"Neuroeconomics is an interdisciplinary research progrom with the goal of bullding a biological model of decision making in economic environments. (More specifically, it) is the study of how the embodied brain interacts with its external environment to produce economic behovior. Research in this field will allow social scientists to better understand individuals" decision making, and consequently to better predict behovior." (McCabe, 2003, p. 294)

At first sight this may sound abstract and relatively remote from public policy issues. Indeed, in the above definition, the first part refers to the "pure scientific' element of neuroeconomics. The second part, however. reflects the potential of this approach for public policy making. Having good models of human behavior is crucial for making good predictions of human behavior in economic situations. Neuroeconomics has the potential to significantly contribute to this quest for better models of economic decision making. When evaluating the potentiai of this new emerging field one may want to recall the history of game theory and laboratory experiments in economics. In its beginnings game theory was largely dismissed as being too acadernic and thought to be useful at most for war strategists but surely not for the analysis of ordinary economic interactions. Nowadays game theory is used for policy advices at a large scale in many countries. (Recall, e.g. the frequency auctions a few years ago where game theorists played a crucial role in designing auction formats.) Later, experimental and behavioral economics was smiled at by many economists because it was the received wisdom in economics that "economists ... cannot perform ... controlled experiments" (Samuelson and Nordhaus, 1985) a view that changed quite a bit over the years as the following quote by the very same authors seven years later testifies. There they state that experimental economics is an "exciting new development." (Samuelson and Nordhaus, 1992) it is not unlikely that neuroeconomics awaits the same "fate".

In any event, both directions - towards the experimental field and towards the brain - can be expected to be one of the most lively areas of research in economics, and both are likely to produce results that will lead to better models, better predictions, better advices, and witimately - hopefully - also to better informed public policies. 


\section{Closing words}

In the course of my talk I discussed a few areas in experimental and behavioral economics that are of importance for public economics and public policy. Naturally, many at least equally important issues were not even slightly touched upon. For instance, voluntary contributions to public goods ${ }^{20}$ "time inconsistent intertemporal decision making (i.e. retirement decisions and pension systems), decision making under risk and uncertainty (i.e. health insurance and social security in general), the role of moral property rights in policy reform ${ }^{27}$ only to name a few. In the future, also the fundamental issue of "welfare analysis beyond revealed preferences' is awaiting public economics, and more generally, economic theory. Only first small steps in this direction are made, yet (Bermheim and Rangel, 2006; Herings and Rohde, 2006).

In recent years, the "facts" of behavioral regularities have been shown to be incompatible with the traditional "fiction" of economic theory. This has led to the developernnt of new theoretical approaches and models. it seems clear that for good public policy we need both good accounts of the behavioral facts and a theoretical fiction that gives us the tools to deal with the upcoming challenges in an accurate way. I hope that my research here at Maastricht University will contribute to the discovery of more exciting facts of human behavior as well as to the development of more thrilling fiction that can account for this behavior.

20. Andreoni (2006) reports (for 1995) that the casth revenues of the non-profit sector in the Netherlands are at 15.5 percent of GDP and 3 percent of the nom-profit sector's cash revenues comes from pure philanthropy.

21. For an experimental account of the importance of moral property rights see e.g. Gächter and Riedl (2005). 


\section{Persomal words and acknowledgment}

Before ending my talk I would like to thank those people who deliberately - or not - supported me in the past and made it possible that 1 stand here today.

At the very beginning of my academic career Egbert Dierker at the University of Vienna was an important mentor who helped me shaping my theoretical thinking in economics. Ernst Fehr and Georg Kirchsteiger were the first with whom I conducted experiments. The short but extremely fruitful collaboration with them was surely decisive for the decision to continue with research in experimental economics.

The Institute for Adwanced Studies in Vienna - founded by Oskar Morgenstern and Paul Lazarsfeld - was an ideal environment for preparing myself for the 'wild world' of academics outside Austria, which l entered in 1998 when moving as a post-doc to the Center for Experimental Economics and political Decision Making (CREED) at the University of Amsterdam. I owe much to the constant factors at CREED who are Theo Offermans, Arthur Schram, Joep Sonnemans, and Frans van Winden. I want to particularly mention, the director of CREED, Frans van Winden who, first of all made it possible that I could move to Amsterdam, and always supported me especially also in times when the referees of some peer-reviewed journals thought that my papers are not as good as they actually are. The open minded scientific atmosphere at CREED, with the help of some finamcial support by the Dutch Science Organization (NWO), made it not only possible to get in contact with scientific tribes economists usually do not mix with - sociologists, psychologisits, and biologists - but also to perform joint research with them. This is a unique mind-opening experience / hope to enjoy also in the future.

I want to thank also my co-authors and friends Ronald Bosman, Jordi Brands, Martijn Egas, Ernst Fehr, Jacob Goeree, Georg Kirchsteiger, Michael Kosfeld, Akira Okada, Hessel Oosterbeek, Ernesto Reuben, Randolph Sloof, Jean-Robert Tyran, Aljaz Ule, Jana Vyrastekowa, and Frans van Winden. One co-author I want to mention explicity: Simon Gächter with whom I not only undertook the longest lasting research projects but who is also a very speciall friend. 
lalso want to thank the Faculty of Economics and Business Administration and, in especially the Department of Economics ${ }_{n}$ to give me the possibility to do teaching and research at Maastricht University. Thanks to the policy of our head of department, Jean-lacques Herings, we are a (relatively) young and, in any event, very dymamic team and I am sure that we can reach our goal of being and staying at the top of research in theoretical, behavioral, experimental, and public economic research. For this aim, like the Red Queen in Lewis, Carroll's Through the Looking Glass. we cannot stand still and, therefore, some new ideas, like extenting the behavioral lab and building up a center for Neuroeconomics jointly with the Faculty of Psychology, are already put forward. I am convinced that these initiatives will also receive the necessary support from the Faculty and University Board. Other initiatives, also in teaching, will surely follow. We gaan er iets leuks van maken.

Ohne meine Eltern, Maria und Manfred Riedl, wäre ich nirgends, und das ist nicht nur eine biologische Binsenweisheit. Meine Eltern haben mich immer unterstützt, wo und wie sie nur konnnten, und sie haben immer an mich geglaubt. Dafür und für alles andere welches aufzuzählen den zeitlichen Rahmen dieser Veranstaltung gehörig sprengen würde danke ich ihnen von tiefem Herzen.

Bärbel, meine Partnerin, ist der Anker in meinem Leben ohne den es mich schon öfters wer weiss wohin getrieben hätte. Ohne sie würde ich nie und nimmer hier stehen ... und alles andere was es noch zu sagen gibt teile ich nicht in der Öffentlichkeit mit. Nur noch dieses: $\infty$.

Mijnheer de Rector,

Dames en heren, ik heb gezegd. 


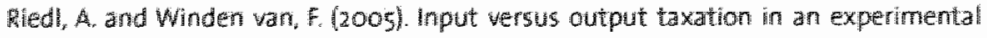
international economy. Technical report, CRECD. Tinoergen Imstitute, Uniwersity of Amsterdam.

Ried, A and Whden van, F (2006). An expermental inwestigation of wage taxation and unemployment in closed and open economies. Europewn Economic Review, forthicoriong

Ruffle, B. I. (2005) Tax and subsidy incidence equivalence theories: Experimental evidence from competivive markets Joumal of Public Economics, $89(8): 1519-3542$.

Samuetson, P. A and Nordhaus, W. D. (1985). Economics. McGraw-Hill, New York, 12

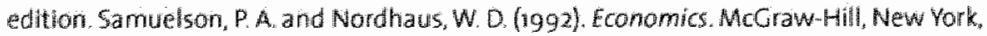
15 edition.

Scheling, T. C. (1968). The life you save may be your own. in Chase, 5 . B, editor, Problems in Public Expenditure Anolysis. The grookings institute. Washington DC.

Simonson, 1. (1990). The effect of purchase quantity and timing on wariety-seeking behavior. Joumal of Marketing Research, 27:150-162.

Simomson, I. and Wimer, R. S. (1992). The infuence of purchase quamity and disply format on consumer preference for variety Joumat of Consumer Research, $191333^{-138}$.

Small, D. A and toewenstein, G. (2003). Heiping a victim or helping the wictim: Atruism and identifiability. Houmal of Risk and uncertainty, 26(1)-5-16.

Stigler, C. J. (1980). Economics or ethic s? Tamner Lectures on Humain Values.

Twersky, A and Kahneman, $0 .(1981)$. The framing of decisions and the psychology of cholce. Science, $211(4481): 453-458$

van Winden, F. A. A. M. Ried, A, Wit, I, and van Dijh, F. (1999). Experimenteel econow miscth onderzoek naar het Plan Wan Elswijk. Eindrapport CREED, Universiteit van Amsterdam.

van Wiriden, F. A. A.M. Riedl, A., Wit, l, and van Dijk, F (zooo). Experiment: het Plan Van Elswijk. Economisch statistische Berichten, 10-3-2000:197-199. 
